\title{
Patofisiologi Infeksi Bakteri pada Kulit
}

\author{
Herry Garna
}

Kulit merupakan barier penting untuk mencegah mikroorganisme dan agen perusak lain masuk ke dalam jaringan yang lebih dalam. Kelainan kulit yang terjadi dapat langsung disebabkan mikroorganisme pada kulit, penyebaran toksin spesifik yang dihasilkan mikroorganisme, atau penyakit sistemik berdasarkan proses imunologik. Sistem imun berkembang dengan fungsi yang khusus dan bekerja di kulit. Sel Langerhans, keratinosit, sel endotel, dendrosit dan sel lainnya semua ikut berperan dalam skin associated lymphoid tissue (SALT). Mediator yang berperan antara lain IL-1, IL-2, IL-3, produk sel mast, limfokin dan sitokin lain yang sebagian besar dihasilkan oleh keratinosit.

Kata kunci: infeksi bakteri - kulit - SALT

$\tau$ ubuh manusia mempunyai berbagai cara untuk melakukan proteksi. Pertahanan pertama adalah barier mekanik, seperti kulit yang menutupi permukaan tubuh. ${ }^{1}$ Kulit termasuk lapisan epidermis, stratum korneum, keratinosit dan lapisan basal bersifat sebagai barier yang penting, mencegah mikroorganisme dan agen perusak potensial lain masuk ke dalam jaringan yang lebih dalam. ${ }^{1,2}$ Misalnya asam laktat dan substansi lain dalam keringat mengatur $\mathrm{pH}$ permukaan epidermis dalam suasana asam yang membantu mencegah kolonisasi oleh bakteri dan organisme lain. ${ }^{1}$

Terdapat berbagai infeksi pada anak disertai dengan kelainan (tanda) pada kulit. Pada beberapa kasus kelainan kulit dapat merupakan tanda penting penyebab infeksi yang merupakan indikator bermakna adanya infeksi yang mendasarinya. Walaupun kebanyakan penyakit eksantema pada anak bersifat ringan, diagnosis banding penting sekali oleh karena beberapa infeksi pada anak yang fatal sering mempunyai kelainan (tanda) pada kulit sebagai manifestasi awal. $^{3}$

Dermis dengan kolagen dan elastin memberikan

Alamat korespondensi:

Prof. Dr. H Herry Garna, Sp.A(K), PhD.

Bagian/SMF Ilmu Kesehatan Anak FK-UNPAD/RSUP Hasan Sadikin, Jl. Pasteur No. 38 Bandung.

Tel. 022-2034426. Fax. 022-2032216, 2011282, 2035957. dukungan dan pencegahan banyak elemen seperti saraf, pembuluh darah, dan lain-lain sedangkan subkutis merupakan insolator panas dan persediaan kalori. Kekurangan kolagen akan memudahkan terjadinya edema, terutama pada bayi prematur. ${ }^{2}$

\section{Biologi Kulit}

Kulit terdiri dari tiga lapisan utama ${ }^{4} 1$. Epidermis (lapisan bagian luar tipis), 2. Dermis (lapisan tengah), 3. Subkutis (bagian paling dalam).

\section{Epidermis}

Lapisan epidermis tebalnya relatif, bervariasi dari 75$150 \mu$, kecuali pada telapak tangan dan kaki lebih tebal; terdiri dari stratum korneum dan lapisan Malpighi, terdapat desmosom, melanosit dan lain-lain.

\section{Dermis}

Ketebalan dermis bervariasi di berbagai tempat tubuh, biasanya $1-4 \mathrm{~mm}$. Dermis merupakan jaringan metabolik aktif, mengandung kolagen, elastin, sel saraf, pembuluh darah dan jaringan limfatik. Juga terdapat kelenjar ekrin, apokrin, sebaseus di samping folikel rambut. 


\section{Subkutis}

Terletak di bawah dermis, terdiri dari jaringan ikat dan lemak.

\section{Perbedaan Struktur Kulit Bayi dan dan Dewasa}

Kulit bayi dibandingkan dengan kulit orang dewasa mempunyai struktur yang agak berbeda.(Tabel 1)

\section{Patogenesis Kelainan Kulit karena Infeksi}

Patogenesis kelainan kulit yang ditimbulkan infeksi dapat dibagi dalam 3 kategori: ${ }^{3}$

1. Mikroorganisme patogen dari aliran darah menyebabkan infeksi sekunder pada kulit.

2. Penyebaran toksin spesifik yang berasal dari mikroorganisme patogen menyebabkan kelainan pada kulit.

3. Penyakit sistemik menimbulkan kelainan kulit karena proses imunologik.

Tabel 1. Perbedaan Struktur Kulit Bayi dan Dewasa

\begin{tabular}{|c|c|c|c|}
\hline & Prematur & Cukup-Bulan & Dewasa \\
\hline Epidermis & $\begin{array}{l}\text { Lebih tipis } \\
\text { Desmosom lebih sedikit } \\
\text { Stratum korneum lebih sedikit } \\
\text { Produksi melanin rendah }\end{array}$ & $\begin{array}{l}\text { Stratum korneum tampak sebagai } \\
\text { lapisan sel adheren } \\
\text { Produksi melanin rendah }\end{array}$ & $\begin{array}{l}\text { Stratum korneum tampak } \\
\text { sebagai lapisan terpisah }\end{array}$ \\
\hline Dermis & $\begin{array}{l}\text { Jaringan ikat elastin lebih sedikit } \\
\text { Lebih tipis daripada dewasa }\end{array}$ & $\begin{array}{l}\text { Jaringan ikat elastin lebih sedikit } \\
\text { Lebih tipis daripada dewasa }\end{array}$ & $\begin{array}{l}\text { Penuh dengan jaringan, } \\
\text { elastin }\end{array}$ \\
\hline Kelenjar ekrin & $\begin{array}{l}\text { Lebih menyerupai pada fetus } \\
\text { Saluran poten } \\
\text { Sel sekretori tak berdiferensiasi }\end{array}$ & $\begin{array}{l}\text { Sama strukturnya dengan dewasa } \\
\text { Distribusi lebih tersebar daripada } \\
\text { dewasa }(977 / \mathrm{cm} 2 \text { pada lengan) }\end{array}$ & $\begin{array}{l}\text { Distribusi kurang padat } \\
\text { daripada bayi ( } 144- \\
241 / \mathrm{cm} 2 \text { pada lengan) }\end{array}$ \\
\hline Kelenjar apokrin & & Kecil, tidak berfungsi & $\begin{array}{l}\text { Pengeluaran keringat } \\
\text { apokrin dalam respons ter } \\
\text { hadap stimuli, mekanik dan } \\
\text { farmakologik }\end{array}$ \\
\hline Rambut & $\begin{array}{l}\text { Lanugo dapat ada } \\
\text { Pertumbuhan rambut sinkron }\end{array}$ & $\begin{array}{l}\text { Rambut vellus khas } \\
\text { Pertumbuhan rambut sinkron }\end{array}$ & $\begin{array}{l}\text { Rambut vellus } \\
\text { Pertumbuhan rambut tak } \\
\text { sinkron }\end{array}$ \\
\hline Kelenjar sebaseus & Besar dan aktif & $\begin{array}{l}\text { Besar dan aktif, tapi menurun } \\
\text { cepat ukuran/aktivitasnya beberapa } \\
\text { minggu sesudah lahir }\end{array}$ & Besar dan aktif \\
\hline $\begin{array}{l}\text { Sistem saraf dan } \\
\text { vaskular }\end{array}$ & $\begin{array}{l}\text { Tak terorganisasi sempurna } \\
\text { Kebanyakan saraf berukuran kecil, } \\
\text { tak bermielin, saraf sensorik } \\
\text { /autonom } \\
\text { Saraf tak bermielin strukturnya } \\
\text { khas seperti fetus } \\
\text { Reseptor Meissner tak terbentuk } \\
\text { sempurna }\end{array}$ & $\begin{array}{l}\text { Sistem vaskular tak terorganisasi } \\
\text { sempurna sampai } 3 \text { bulan } \\
\text { Jaringan saraf kulit tak berkembang } \\
\text { sempurna, berkembang terus sampai } \\
\text { pubertas } \\
\text { Kebanyakan saraf berdiameter kecil, } \\
\text { tak bermielin, saraf sensorik/autonom } \\
\text { Reseptor Meissner tak terbentuk } \\
\text { sempurna }\end{array}$ & Pola dewasa \\
\hline
\end{tabular}




\section{Mikroorganisme patogen yang me- nyebar ke dalam darah, menyebabkan infeksi sekunder pada kulit}

Kelainan kulit pada keadaan ini dapat langsung akibat mikroorganisme patogen itu pada epidermis, dermis, atau endotel kapiler dermis, atau dapat disebabkan respons imun antara organisme dan antibodi atau faktor selular pada kulit.

Tahap pertama pertahanan adalah mekanisme

Tabel 2. Sel yang berperan dalam SALT

\begin{tabular}{|c|c|}
\hline Sel & Mekanisme Kerja \\
\hline Keratinosit & $\begin{array}{l}\text { Sekresi sitokin } \\
\text { Sekresi IL-1 dan melepaskannya ke } \\
\text { daerah yang mengalami kerusakan } \\
\text { Melepaskan mediator } \\
\text { Memproses antigen dan } \\
\text { mempresentasikan }\end{array}$ \\
\hline Sel Langerhans & $\begin{array}{l}\text { Memproses antigen } \\
\text { Mempresentasikan antigen ke sel } \mathrm{T} \\
\text { helper } \\
\text { Melepaskan mediator }\end{array}$ \\
\hline Dendrosit kulit & $\begin{array}{l}\text { Memproses dan mempresentasikan } \\
\text { antigen }\end{array}$ \\
\hline Makrofag kulit & $\begin{array}{l}\text { Memproses dan mempresentasikan } \\
\text { antigen } \\
\text { Fagositosis } \\
\text { Melepaskan mediator }\end{array}$ \\
\hline Sel vailed & Transport antigen ke kelenjar limfe \\
\hline Sel T gamma/delta & $\begin{array}{l}\text { Memulai respons imun non-spesifik } \\
\text { Mempresentasikan antigen ke sel } \mathrm{T} \\
\text { supresor (?) }\end{array}$ \\
\hline Limfosit & $\begin{array}{l}\text { Respons imun selular } \\
\text { Mengontrol dan mengatur respons } \\
\text { imun dan inflamasi } \\
\text { Sekresi limfokin } \\
\text { Bersifat sitotoksik }\end{array}$ \\
\hline Leukosit PMN & $\begin{array}{l}\text { Fagositosis } \\
\text { Melepaskan mediator }\end{array}$ \\
\hline Sel mast & $\begin{array}{l}\text { Aktivitas anafilaksis } \\
\text { Melepaskan mediator }\end{array}$ \\
\hline Cairan jaringan & $\begin{array}{l}\text { Penghantar antibodi } \\
\text { Sel endotel Permeabilitas } \\
\text { pembuluh darah } \\
\text { Entrapment limfosit }\end{array}$ \\
\hline
\end{tabular}

antibakteri yang tidak tergantung dari pengenalan antigen. Kulit dan permukaan epitel mempunyai sistem non-spesifik atau innate protective system yang membatasi masuknya organisme invasif.. Asam lemak yang dihasilkan kulit juga bersifat toksik terhadap banyak organisme. ${ }^{5}$

Kulit merupakan barier fisik yang dapat mempertahankan tubuh dari agen patogen. Apabila terdapat kerusakan kulit, maka kulit akan mempertahankan tubuh dengan proses imunologik yang cepat terhadap agen patogen tersebut dan mengeluarkan mikroorganisme tersebut dari epidermis dan dermis. ${ }^{6}$

Sistem imun berkembang dengan fungsi yang khusus dan bekerja pada kulit. Sel Langerhans, dendrosit kulit, sel endotel, keratinosit dan sel lainnya semuanya ikut berpartisipasi dalam skin associated lymphoid tissue (SALT) yang mempunyai sistem imun pada kulit. ${ }^{6,7}$ Ketika mikroorganisme menembus barier kulit akan merangsang respons imun. Kulit seperti halnya organ lain akan merusak mikroorganisme tersebut dan mengeliminasi antigen. ${ }^{6}$

Tabel 3. Sitokin yang Dihasilkan Keratinosit ${ }^{6}$

\begin{tabular}{ll}
\hline Sitokin & Jenis \\
\hline Interleukin & IL-1 \\
& IL-3 \\
& IL-6 \\
IL-7 \\
IL-8 \\
IL-10 \\
IL-12 \\
Colony-stimulating factor & GM CSF \\
& G-CSF \\
Lain-lain & M-CSF \\
& Asetilkolin \\
& TGF $\alpha$ \\
& TGF $\beta$ \\
& TNF $\alpha$ \\
& IP-10, dll \\
\hline
\end{tabular}

Varisela, infeksi enterovirus dan meningococcemia merupakan contoh mikroorganisme sampai ke kulit melalui aliran darah dan menyebabkan kelainan pada kulit tanpa kontribusi faktor imun pejamu. Pada penyakit seperti morbili, rubela dan gonococcemia sukarnya mikroorganisme ditemukan pada kultur 
menandakan kemungkinan efek langsung atau peranan respons imun (immune-mediated response).

Banyak penelitian telah dilakukan untuk menentukan keasaman yang berbeda pada kulit yang berbeda pada waktu yang berbeda dan pada individu yang berbeda. Umumnya dikatakan bahwa $\mathrm{pH}$ normal kulit berfluktuasi antara 4,2 dan 7,0 (rata-rata 5,2)

Reaksi asam kulit dapat membunuh kebanyakan bakteri patogen. Asam laktat telah lama dipakai untuk keasaman kulit sejak tahun1934, Marchionini melaporkan keberhasilan terapi dengan asam laktat pada pasien seborrheic eczema. Sedangkan Pennoyer dan Sullivan melaporkan pada tahun 1954 bahwa mereka telah berhasil dalam menurunkan insidens impetigo pada bayi dari $2 \%$ menjadi $0,13 \%$ dengan memakai preparat yang mengandung asam laktat. ${ }^{8}$

Penelitian multisenter pemakaian Lactacyd di Perancis telah dilaporkan oleh dokter umum, dokter kulit dan dokter anak pada pasien dengan seborrheic dermatitis, hiperhidrosis dan diaper rash menunjukkan efikasi 87,6\% dan tidak ditemukan efek samping. ${ }^{9}$

\section{Patogenesis berhubungan dengan penyebaran toksin spesifik yang berasal dari mikroorganisme patogen}

Infeksi mikroorganisme pada daerah lokal, namun toksin yang dibebaskan mencapai kulit melalui aliran darah. Seperti diketahui bakteri mempunyai banyak antigen permukaan yang berbeda dan mengeluarkan bermacam-macam faktor virulen (misalnya toksin) yang dapat merangsang respons imun. ${ }^{10}$

Contoh penyakit eksantema yang disebabkan toksin ini adalah demam skarlet karena streptokokus, toxic shock syndrome, dan lain-lain. Streptokokus merupakan kokus Gram-positif, anaerob, menyebabkan infeksi toksigenik dan piogenik pada manusia, seperti pada demam skarlet (eksotoksin). ${ }^{10}$

Stafilokokus merupakan kokus Gram-positif, fakultatif anaerob, merupakan patogen kulit yang paling prevalen. Pertahanan pertama terhadap stafilokokus adalah leukosit PMN yang memfagositosis dan membunuh bakteri. Staphylococcus aureus menghasilkan sejumlah faktor virulen termasuk toksin yang menentukan patogenisitasnya. S. aureus mengeluarkan exfoliative toxin yang menyebabkan nekrolisis epidermis dan eksotoksin yang menyebabkan toxic shock syndrome. Galur stafilokokus lain yang menyebabkan penyakit pada manusia adalah $S$. epidermis, merupakan flora bakteri pada kulit yang sering ditemukan. ${ }^{10}$

Infeksi nosokomial karena bakteri pada bayi baru lahir selama perawatan di ruang bersalin terutama disebabkan S. aureus. Penelitian yang dilaporkan Meberg dan Schoyen menunjukkan terjadi penurunan insidens infeksi S. aureus (pioderma, infeksi umbilikus) selama 3 minggu pertama kehidupan sesudah pemberian Hibiscrub sebagai disinfeksi umbilikus. ${ }^{11}$

\section{Terjadinya kelainan kulit pada penyakit sistemik yang kurang dimengerti, namun tampaknya mempunyai dasar imuno- logik}

Umumnya tidak dapat diidentifikasi baik lokasi antigen ataupun toksin yang dibebaskan. Kelainan kulit yang terpenting pada kategori ini adalah eritema nodosum dan eritema multiforme.

\section{Proses terjadinya respons imun}

Antigen terikat pada sel yang dapat mempresentasikan antigen seperti sel Langerhans, makrofag dan dendrosit dermis. Sel tersebut akan memproses antigen dan mempresentasikan fragmen antigen kepada limfosit spesifik. ${ }^{6}$ Dalam keadaan normal sejumlah kecil limfosit akan melalui dermis di luar pembuluh darah. Limfosit kemudian akan membentuk sel inflamasi perivaskular. Banyak ahli imunologis berpendapat bahwa populasi limfosit di kulit dilengkapi oleh suatu program untuk beraksi dengan antigen yang sebelumnya telah pernah kontak dengan kulit. Sirkulasi limfosit dari kulit ke kelenjar limfe kembali ke kulit disebut homing. Limfosit homing masuk ke dalam kulit yang tidak mengalami inflamasi untuk mencari adanya antigen. Bila ada antigen, limfosit akan mengaktivasi sel endotel gepeng untuk mengumpulkan limfosit lain sebagai bagian dari reaksi inflamasi yang ditimbulkannya. Bila limfosit spesifik yang telah tersentisisasi bereaksi dengan antigen, respons imun dapat timbul. Kurang lebih 5\% dari limfosit di dermis pada reaksi imun yang diperantarai oleh sel adalah limfosit yang secara spesifik bereaksi terhadap antigen. Limfosit tambahan dapat dikumpulkan ke area tersebut oleh limfokin yang dikeluarkan oleh limfosit spesifik sebagai respons terhadap adanya antigen. Respons imun dapat pula ditimbulkan di epidermis. Sel T masuk ke dalam 
epidermis dari dermis. Agar hal ini dapat terjadi sel T harus melewati daerah membran basalis dan menembus keratinosit. Substansi mediator seperti IL-8 dianggap berperan terhadap penarikan limfosit ke dalam epidermis. Keratinosit memproduksi IL-8 terutama bila dirangsang oleh gamma-interferon. Bila telah terdapat dalam epidermis, limfosit dapat diaktivasi oleh sel Langerhans. Keadaan ini dapat memperkuat respons imun dan membantu eliminasi antigen atau menghancurkan sel yang terinfeksi. Sejumlah sel helper dan sel supresor pada infiltrat akan mengatur proses inflamasi yang terjadi. ${ }^{6}$

\section{Kesimpulan}

Epidermis saat ini tidak lagi dapat dipandang hanya sebagai barier fisik sederhana saja. Demikian pula dermis tidak dapat lagi dianggap sebagai satu-satunya area tempat terjadinya proses imunologik di kulit. Kulit secara keseluruhan berperan aktif sebagai sistem imun terhadap bermacam-macam antigen. Sel yang aktif secara imunologik meliputi sel Langerhans, keratinosit, sel T, sel endotel, dan makrofag. Sel efektornya adalah limfosit, natural killer cell, sel mast dan fagosit. Mediator yang ada meliputi IL-1, IL-2, IL-3, produk sel mast, limfokin, sitokin lain, sejumlah besar dihasilkan oleh keratinosit. Interaksi antara antigen dan sel epidermis serta dermis dapat mengindukasi dan menimbulkan respons imun. Reaksi yang timbul merupakan dasar dari berbagai proses inflamasi pada kulit.

\section{Daftar Pustaka}

1. Parslow TG, Baunston DF. Innate immunity. Dalam: Stites DP, Terr AL, Parslow TG, penyunting. Medical immunology; edisi ke-9. London: Prentice-Hall Internat Inc, 1977. h. 25-42.

2. Giam YC. Neonatal physiology and skin care. Diajukan pada 3rd Regional Scientific Meeting on Pediatric Dermatology, South Easat Asia \& Western Pacific, Singapore 5-8 Nov 1999.

3. Thisyakom U. Skin signs of pediatric infection. Diajukan pada 3rd Regional Scientific Meeting on Pediatric Dermatology, South East Asia \& Western Pacific, Singapore 5-8 Nov 1999.

4. Johnson \& Johnson. Principles of infant skin care. Johnson \& Johnson Consumer Product, Inc:6-12.

5. Roitt I, Brostoff J, Male D. Immunology; edisi ke-4. London: Mosby 1996. h. 1-13.

6. Dahl MV. Clinical immunodermatology; edisi ke-3. St. Louis: Mosby 1996. h. 121-31.

7. Tigelaar RE. Selected advances in cutaneous immunobiology and our understanding of skin-associated lymphoid tissue. Dalam: Dyall-Smith D, Marks R, penyunting. Dermatology at the millenium; edisi ke1. New York: The Parthenon Publ Group, 1999; 4654.

8. Langerholm B, Lodin A. New acidifying preparation for skin care. Lakartidningen, 1966; 63:1472-6.

9. Daniel F, Rabary G. Multicenter trial with lactacyd. Gasette meicale, 1984;91.

10. Ryan JL. Bacterial diseases. Dalam: Stites DP, Terr AL, Parslow TG, penyunting. Medical immunology; edisi ke9. London: Prentice-Hall intern Inc, 1977; 684-93.

11. Meberg A, Schoyen R. Bacterial colonisation and neonatal infections. Acta Paediat Scand 1985; 74:36671. 